\title{
Karyotypic description of four species of Trigona (Jurine, 1807) (Hymenoptera, Apidae, Meliponini) from the State of Mato Grosso, Brazil
}

\author{
Kleber França Costa $^{2}$, Rute Magalhães Brito ${ }^{1}$ and Carlos Suetoshi Miyazawa ${ }^{2}$ \\ ${ }^{1}$ Universidade de São Paulo, Instituto de Biociências, São Paulo, SP, Brazil. \\ ${ }^{2}$ Universidade Federal de Mato Grosso, Instituto de Biociências, Departamento de Biologia \\ e Zoologia, Cuiabá, MT, Brazil.
}

\begin{abstract}
The genus Trigona contains at least 31 species, but there have been few cytogenetic studies of this group. In this work, four species of Trigona (T. branneri, T. chanchamayoensis, T. hyalinata, and T. recursa) from the municipality of Cuiabá, in the State of Mato Grosso, Brazil, were studied. In all of the species, the females had $2 n=34$ chromosomes and the males had $n=17$. The $\mathrm{C}$-banding patterns showed that the karyotypes of these species consisted mainly of acrocentric and pseudoacrocentric chromosomes. These cytogenetic findings should useful in future phylogenetic studies of this group.
\end{abstract}

Key words: cytogenetics, karyotype, Meliponini, stingless bees, Trigona .

Received: January 6, 2003; Accepted: November 14, 2003.

\section{Introduction}

The Brazilian state of Mato Grosso has three distinct biomes ("Cerrado", Amazon rain forest and Pantanal wetlands) and an important faunal and floral diversity. However, there is very little information on the apifauna of Mato Grosso and still no list of the bee species that occur in this state.

The tribe Meliponini (stingless bees) is highly diversified in the Neotropics, with 52 genera and more that 300 species found in the Americas (Velthuis, 1997). These bees are of considerable ecological and economic importance because they are responsible for the pollination of $40-90 \%$ of plant species, depending on the ecosystem (Kerr et al., 1996).

Bees of the genus Trigona, popularly known as xupé, mombuca and sanharão, show a variety of defense behaviors and a range of nesting habits, with nests being built on branches of plants or on walls, anthills or underground. This group of bees is widespread in the Neotropics (from Mexico to Argentina), in Asia (from India and Sri-Lanka to Taiwan), in the Pacific region (Carolina and Solomon islands, southern Indonesia and New Guinea), and in some regions of Australia (Michener, 2000). Some species of

Send correspondence to Carlos S. Miyazawa. Universidade Federal de Mato Grosso, Instituto de Biociências, Departamento de Biologia e Zoologia. Rua Três n. 106, Recanto dos Pássaros, 78075-230 Cuiabá, MT, Brazil. E-mail: carlosmiyazawa@bol. com.br.
Trigona are important in the pollination of certain palm species of the Brazilian Cerrado (Oliveira, 1998) and may have an important role in nutrient dispersal since they are frequently seen collecting animal feces.

To date, only five species of Trigona have been studied cytogenetically and include $T$. fuscipennis, $T$. recursa (Tarelho, 1973), T. barrocoloralensis and T. minangkabau (Hoshiba and Imai, 1993) and T. spinipes (Brito and Pompolo, 1997). These investigations have been limited to a description of chromosome numbers based on acetic-orcein staining, which does not allow efficient visualization of the chromosomal morphology. The aim of this study was to cytogenetically characterize four species of Trigona in order to obtain data that could be useful for future phylogenetic studies of this group.

\section{Material and Methods}

The four species of Trigona studied (T. branneri, $T$. chanchamayoensis, T. hyalinata and T. recursa) were collected from nests in and around Cuiabá, capital of the State of Mato Grosso, Brazil. Adult specimens were identified to the species level by Dr. Jesus Santiago Moure, Dr. Gabriel Rodrigues de Melo and Maria Christina de Almeida, MSc (all in the Department of the Universidade Federal do Paraná, Curitiba, PR, Brazil).

The cytogenetic mounts were prepared from the cerebral ganglia of post-defecating larvae as described by Imai et al. (1988). Constitutive heterochromatin was detected as 
described by Sumner (1972), with the modifications of Pompolo and Takahashi (1990), and by staining with distamycin-chromomycin $\mathrm{A}_{3}$ (DA/CMA $)$ using an adaptation of the method of Schmid (1980). On average, 20 metaphases were analyzed per slide in a total of 40 slides per species. The best metaphases were photographed in a LEICA DMLS photomicroscope using IMAGELINK film and printed on Kodak F3 Kodabrome paper.

After pairing, the chromosomes were classified as acrocentric $(A)$, totally euchromatic acrocentric $\left(A^{e}\right)$, pseudoacrocentric $\left(\mathrm{A}^{\mathrm{M}}\right)$ or totally heterochromatic metacentric $\left(\overline{\mathrm{M}}^{\mathrm{h}}\right)$, based on the location of the constitutive heterochromatin and on the nomenclature proposed by Imai (1999).

\section{Results and Discussion}

The chromosomal number for the females of the four species was identical $(2 \mathrm{n}=34)$, with $\mathrm{n}=17$ for the males, as also observed for T. fuscipennis, T. recursa (Tarelho, 1973) and T. spinipes (Brito and Pompolo, 1997) (Figures 1 and 2). The karyotypic formulas based on the C-banding patterns (Imai, 1991) are shown in Table 1. These findings differed from those obtained for T. spinipes in which most of the chromosomes are metacentric $\left(\overline{\mathrm{M}}^{\mathrm{c}}\right)$, but agreed with the main types of chromosomes obtained for Meliponini species (Hoshiba and Imai, 1993; Menezes, 1997; Moreira, 1997; Caixeiro, 1999).

Homologies were observed among the euchromatic acrocentric $\left(\mathrm{A}^{\mathrm{e}}\right)$ chromosomal pairs of $T$. chancha-

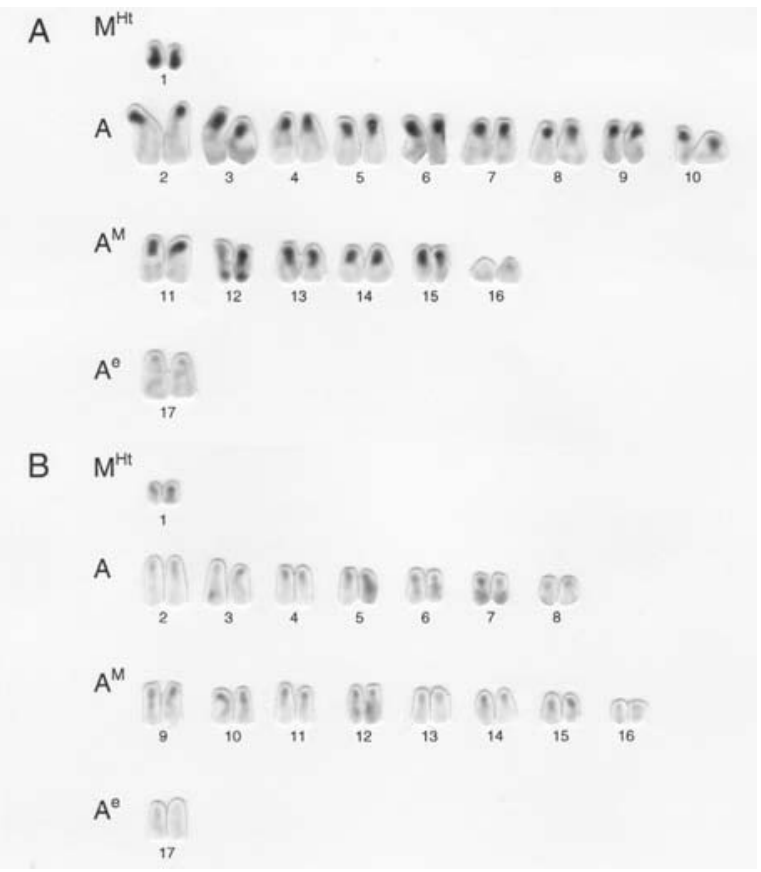

Figure 1 - Karyotypes assembled from metaphases of female Trigona chanchamayoensis (A) and Trigona branneri (B) following C-banding. The nomenclature is based on that proposed by Imai (1991).
Table 1 - Chromosomal types in four species of Trigona based on the nomenclature proposed by Imai (1991).

\begin{tabular}{lcccc}
\hline Species & \multicolumn{4}{c}{ Chromosomal type } \\
\cline { 2 - 5 } & $\mathrm{A}$ & $\mathrm{A}^{\mathrm{M}}$ & $\overline{\mathrm{M}}^{\mathrm{h}}$ & $\mathrm{Ae}$ \\
\hline T. branneri & 7 & 8 & 1 & - \\
T. chanchamayoensis & 9 & 6 & 1 & 1 \\
T. hyalinata & 2 & 14 & - & 1 \\
T. recursa & 6 & 9 & 1 & 1 \\
\hline
\end{tabular}

A: acrocentric, $\mathrm{A}^{\mathrm{e}}$ : totally euchromatic acrocentric, AM: pseudoacrocentric, $\overline{\mathrm{M}}^{\mathrm{h}}$ : totally heterochromatic metacentric.

mayoensis, T. hyalinata and T. recursa, as already reported for T. spinipes (Brito and Pompolo, 1997). Homologies were also noted for the totally heterochromatic metacentric pair $\left(\overline{\mathrm{M}}^{\mathrm{h}}\right)$ of Trigona branneri, T. chanchamayoensis and $T$. recursa (Figures 1 and 2).

Staining with $\mathrm{DA} / \mathrm{CMA}_{3}$ revealed the presence of positive spots on four non-homologous chromosomes of $T$. branneri (Figure 3A,B) that resembled those already observed in T. spinipes (Brito and Pompolo, 1997). In the other chromosomes of $T$. branneri, there was a homogenous pattern of staining with $\mathrm{DA} / \mathrm{CMA}_{3}$ that coincided with the positive C-bands (Figures 1A and 3A,B). In T. chanchamayoensis, a marked reaction was seen with $\mathrm{DA} / \mathrm{CMA}_{3}$ (Figure 4A), while in T. recursa, the staining with $\mathrm{CMA}_{3}$ revealed no GC-rich regions in the chromosomes (Figure 4B). The positive reactions seen were probably associated with nucleolus organizing regions (NORs), as observed in

A $M^{\prime+1}$

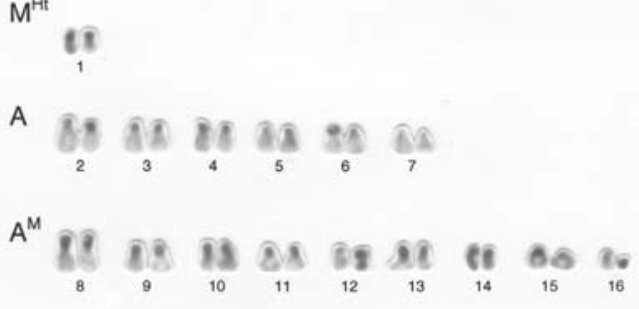

$A^{e}$

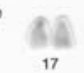

B A
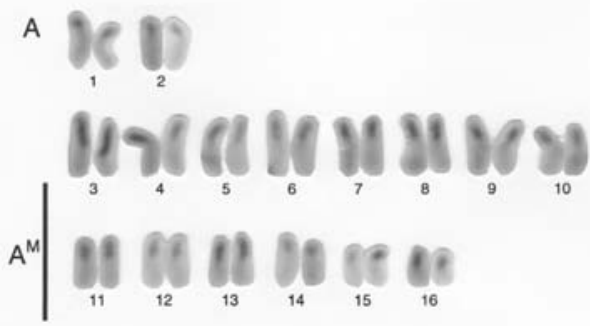

$A^{e}$

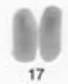

Figure 2 - Karyotypes assembled from metaphases of female Trigona recursa (A) and Trigona hyalinata (B) following C-banding. 

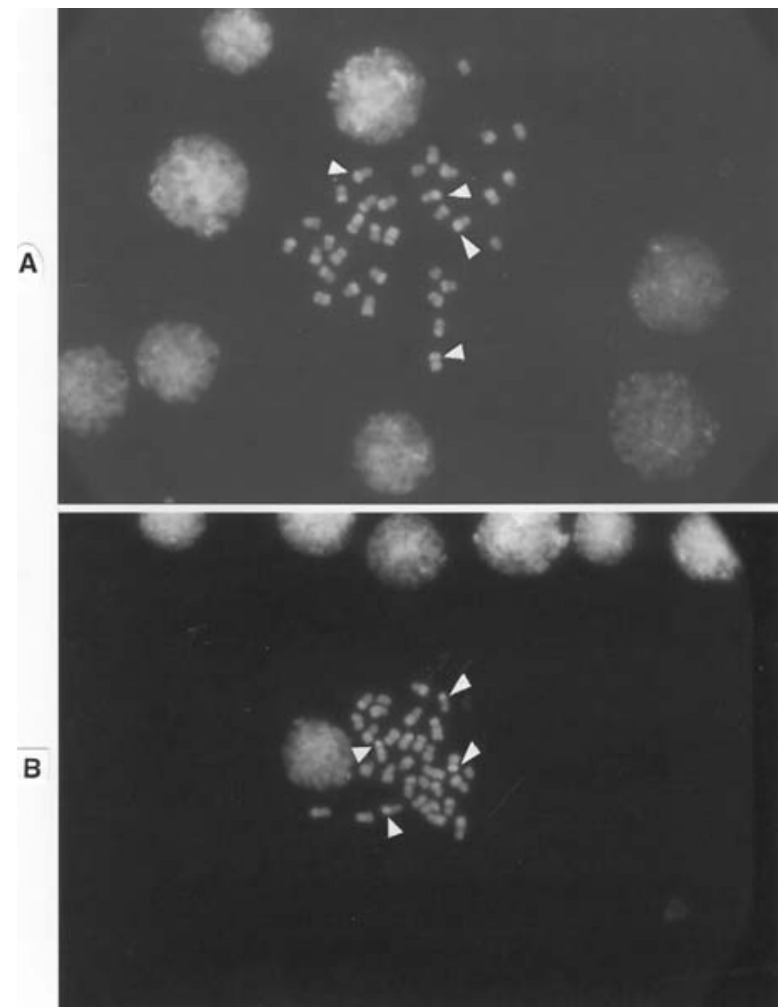

Figure 3 - Metaphases of female Trigona branneri after staining with $\mathrm{DA} / \mathrm{CMA}_{3}$.

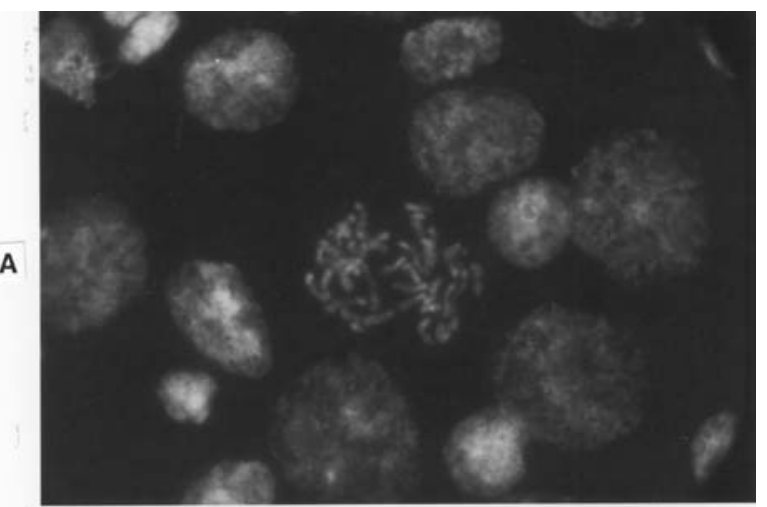

B

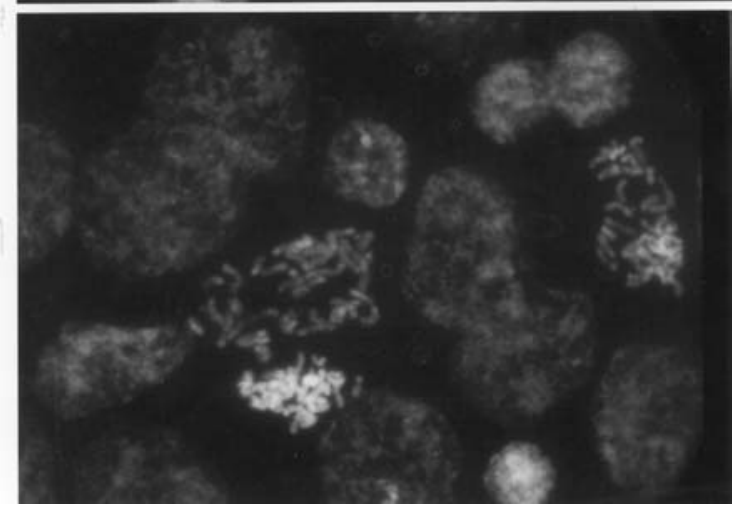

Figure 4 - Metaphases of female Trigona chanchamayoensis (A) and Trigona recursa $(\mathrm{B})$ after staining with $\mathrm{DA} / \mathrm{CMA}_{3}$. other insects such as Orthoptera (Camacho et al., 1991), Coleoptera (Maffei et al., 2001), and in other Hymenoptera, including Formicidae (Palomeque et al., 1988; Imai et al., 1992), Sphecidae (Araújo et al., 2000) and Meliponini (Brito et al., 1999, 2003; Caixeiro, 1999; Rocha, 2000). Some authors have suggested that the number of NORs revealed by impregnation with silver nitrate or by $\mathrm{CMA}_{3}$ staining is an important taxonomic character. Other methods that detect NORs, such as fluorescent in situ hybridization (FISH) with rDNA probes, need to be applied to Trigona species, especially $T$. recursa.

Since there are more than 300 species in the Meliponini, with only about $25 \%$ of them having been studied cytogenetically, more genetic data are necessary for this tribe. Studies of the genus Trigona in other biomes should contribute to our knowledge of the karyotypic diversity among these bees.

\section{Acknowledgements}

The authors thank Dr. Gabriel Rodrigues de Melo for identifying the bees and Dra. Marinêz Isaac Marques for suggests. This work was supported by Conselho Nacional de Desenvolvimento Científico e Tecnológico (CNPq), Fundação de Amparo à Pesquisa de Mato Grosso (FAPEMAT) and Coordenação de Aperfeiçoamento de Pessoal de Nível Superior (CAPES).

\section{References}

Araújo SMSR, Pompolo SG, Dergam JAS and Campos LAO (2000) The B chromosome system of Trypoxylon (Trypargilum) albitarse (Hymenoptera, Sphecidae). Banding analysis Cytobios 101:7-13.

Brito RM, Caixeiro APA, Pompolo SG and Azevedo GG (2003) Cytogenetic data of Partamona peckolti (Hymenoptera, Apidae, Meliponini) by $\mathrm{C}$ banding and fluorochrome staining with DA/CMA3 and DA/DAPI. Genet Mol Biol 26:5357.

Brito RM and Pompolo SG (1997) C:G patterns and fluorochrome staining with DAPI and CMA3, in Trigona spinipes (Jurine, 1807) (Hymenoptera, Apidae, Meliponinae). Braz J Genet 20:62.

Brito RM, Pompolo SG and Miyazawa CS (1999) First karyotype characterization of four species of Partamona (Friese, 1980) (Hymenoptera, Apidae, Meliponinae) in Mato Grosso State, Brazil. Cytobios 100:19-26.

Caixeiro APA (1999) Caracterização citogenética de heterocromatina constitutiva e sua implicação na evolução do cariótipo de espécies do gênero Plebeia (Hymenoptera, Apinae: Meliponini). Masters Thesis, Universidade Federal de Viçosa, Viçosa, Brazil.

Camacho JPM, Cabrero J, Viseras E, Lopez-Leon MD, NavasCastillo J and Alche JP (1991) G banding in two species of grasshoppers and its relationships to $\mathrm{C}, \mathrm{N}$ and fluorescence banding techniques. Genome 34:638-643.

Hoshiba H and Imai HT (1993) Chromosome evolution of bees and wasps (Hymenoptera, Apocrita) on the basis of Cbanding patterns analyses. Jpn J Genet 61:465-492. 
Imai HT (1991) Mutability of constitutive heterochromatin (Cbands) during eukaryotic chromosomal evolution and their cytological meaning. Jpn J Genet 66:635-661.

Imai HT, Hirai H and Satta Y (1992) Phase specific Ag-staining of nucleolar organizer regions (NORs) and kinetochores in the Australian ant Myrmecia croslandi. Jpn J Genet 67:437-447.

Imai HT, Taylor RLW, Crosland MWJ and Crozier RH (1988) Modes of spontaneous chromosomal mutation and karyotype evolution in ants with reference to the minimum interaction hypothesis. Jpn J Genet 63:159-185.

Kerr WE, Carvalho GA and Nascimento VA (1996) Abelha Uruçu. Biologia, Manejo e Conservação. Acangaú, Belo Horizonte, $144 \mathrm{pp}$.

Maffei EMD, Pompolo SG, Campos LAO and Petitpierre E (2001) Sequential FISH analysis with rDNA genes and AgNOR banding in the lady beetle Olla vnigrum (Coleoptera: Coccinellidae). Hereditas 135:13-18.

Menezes MBF (1997) Caracterização citogenética e análise da heterocromatina constitutiva em Tetragonisca angustula (Hymenoptera, Meliponinae). Masters Thesis, Universidade Federal de Viçosa, Viçosa, Brazil.

Michener CD (2000) The Bees of the World. The Johns Hopkins University Press, Baltimore and London, $925 \mathrm{pp}$.

Moreira CMLC (1997) Caracterização cariotípica de três espécies do gênero Frieseomelitta (Hymenoptera, Apidae, Meliponinae). Masters Thesis, Universidade Federal de Viçosa, Viçosa, Brazil.
Oliveira PEAM (1998) Abelhas e a polinização do cerrado. Anais do $3^{\circ}$ Encontro Sobre Abelhas. Ribeirão Preto, SP, Brazil, pp 67-74.

Palomeque T, Cano MA and Díaz de la Guardia R (1988) Karyotypes, c-banding, and chromosomal location of active nucleolar organizing regions in Tapinoma (Hymenoptera, Formicidae). Genome 30:277-280.

Pompolo SG and Takahashi CS (1990) Chromosome numbers and C-banding in two wasps species of the genus Polistes (Hymenoptera, Polistinae, Polistini). Insectes Sociaux 37:251-257.

Rocha MP (2000) Análise cariotípica de dez espeçies de abelhas do gênero Melipona Illiger, 1806 (Hymenoptera, Apidae), baseada em padrões de hetercromatina. Masters Thesis, Universidade Federal de Viçosa, Viçosa, Brazil.

Schmid M (1980) Chromosome banding in Amphibia. IV. Differentiation of GC and AT-rich regions in Anura. Chromosoma 77:83-103.

Sumner AP (1972) A simple technique for demonstrating centromeric heterochromatin. Exp Cell Res 75:304-306.

Tarelho ZVS (1973) Contribuição ao estudo citogenético dos Apoidea. Masters Thesis, Universidade de São Paulo, Ribeirão Preto, Brazil.

Velthuis HHW (1997) Biologia das Abelhas sem Ferrão. USP and Universidade de Utrecht, São Paulo, 33 pp.

Editor Associado: Yatiyo Yonenaga-Yassuda 